\title{
DEVELOPMENT AND EVALUATION OF ANTI-ACNE GEL CONTAINING GARLIC (ALLIUM SATIVUM) AGAINST PROPIONIBACTERIUM ACNES
}

\author{
NYI MEKAR SAPTARINI ${ }^{1 *}$, IRMA ERIKA HERAWATI ${ }^{2}$ \\ ${ }^{1}$ Department of Pharmaceutical Analysis and Medicinal Chemistry, Faculty of Pharmacy, Padjadjaran University, Jl Raya Bandung \\ Sumedang Km 21, West Java, Indonesia. ${ }^{2}$ Departement of Pharmacy, Faculty of Math and Natural Science, University of Al Ghifari, \\ Jl Cisaranten Kulon 140, West Java, Indonesia. Email: nyi.mekar@unpad.ac.id
}

Received: 19 April 2017, Revised and Accepted: 10 May 2017

ABSTRACT

Objective: The aim of this study is to develop and evaluate the gel of garlic juice as anti-acne to facilitate the topical usage.

Methods: The steps of this study consisted of extraction, gel formulations with various concentrations of carboxymethyl cellulose (CMC), and gel evaluation, i.e., organoleptic, viscosity, pH, skin irritation test, hedonic test, and anti-acne activity assay against Propionibacterium acnes.

Results: The garlic juice contains alkaloids, saponins, tannins, monoterpenes, and sesquiterpenes. The different concentrations of CMC produce different physicochemistry properties of the gels. These properties were affected the gels stability, anti-acne activity, and the panelis perception on hedonic test.

Conclusion: The garlic juice at 7.5\% has anti-acne activity to P. acnes, and the gel of 3\% CMC is the most stable and preferable.

Keywords: Garlic juice, Carboxymethyl cellulose, Gel evaluation, Propionibacterium acnes.

(C) 2017 The Authors. Published by Innovare Academic Sciences Pvt Ltd. This is an open access article under the CC BY license (http://creativecommons. org/licenses/by/4. 0/) DOI: http://dx.doi.org/10.22159/ajpcr.2017.v10i8.19271

\section{INTRODUCTION}

Acne is one of the most common multifactorial chronic inflammatory diseases of the pilosebaceous follicles involving altered follicular keratinization, androgen induced sebaceous hyperplasia, hormonal imbalance, immune hypersensitivity, and bacteria (Propionibacterium acnes) colonization [1,2]. P. acnes is an anaerobic Gram-positive bacterium that produces propionic and acetic acid [3]. These bacteria are involved in the development of inflammatory acne by activating complements and metabolizing sebaceous triglycerides into fatty acids that irritate the follicular wall and surrounding dermis. It also produces exoenzymes and chemotactically attracts neutrophils [4]. The sustained antibiotic application entails the antibiotic resistance, which involving the specific nature of the relationship of bacteria to antibiotics [5]. It is sufficient purposes for searching alternative remedies to resolve these problems, including the medicinal plants. Traditional herbal medicines provide an interesting and unexplored source for the antiacne development, such as garlic (Allium sativum).

Indonesian people use the garlic for the treatment of hypertension, asthma, cough, common cold, headache, jaundice, hemorrhoid, constipation, ulcers bruises, abscesses, insect bite, insomnia, antimicrobial, carminative, expectorant, and sedative [6]. Garlic contains some sulfur-containing compounds such as allicin, alliin, ajoene, diallyl sulfide, dithin, S-allyl cysteine, some nonsulfur-containing compounds including vitamin B, proteins, minerals, saponins, and flavonoids [7]. Garlic has antimicrobial activity against Escherichia coli, Bacillus subtilis, Pseudomonas fluorescens, Serratia marcescens, Citrobacter freundii, Klebsiella pneumoniae, Staphylococcus aureus, and Proteus vulgaris [8]. Kodera et al. have been reported a phytoalexin called allixin in garlic [9]. Applications of garlic juice directly on the acne are troublesome. Hence, it is necessary to develop topical dosage forms, such as gel. Gel gives more cold sensation on the skin, easily absorbed and forms a film that is easy to wash. The objective of this study was to develop and evaluate the anti-acne gel containing garlic juice against $P$. acnes to facilitate the topical usage.

\section{MATERIALS AND METHODS}

Materials

Garlic bulbs were obtained from Manoko Lembang, West Java, Indonesia, and identified by School of Biological Sciences and Technology, Bandung Institute of Technology, Indonesia No. 1818/11.C02.2/PL/2012. P. acnes ATCC 11828 were obtained from the Microbiology Laboratory, School of Pharmacy, Bandung Institute of Technology, Indonesia.

\section{Methods}

Extraction

The papery skin of garlic cloves was removed, then weighed $500 \mathrm{~g}$, crushed and squeezed. Phytochemical screening was carried out according to the color reaction [10].

\section{Standardized bacterial culture}

The culture of $P$. acnes was standardized by spectrophotometric method using McFarland turbidity standard. The inoculum suspension was prepared by picking several colonies and suspending the material in $5 \mathrm{~mL}$ sterile $0.85 \%$ sodium chloride to match that 0.5 McFarland turbidity standard. This produced a cell suspension containing $1 \times 10^{6}$ cells per $\mathrm{mL}$, which was diluted in the ratio $1: 100$ with the desired test medium to provide starting inoculum of $1 \times 10^{4}$ cells per $\mathrm{mL}$ [11]

\section{Antimicrobial activity assay of garlic juice}

The bacteria suspension $(25 \mu \mathrm{L})$ and $20 \mathrm{~mL}$ of nutrient agar were dispensed into sterile Petri dishes and allowed to solidify $(n=3)$. The solid agar was riddled with a perforator, then put $50 \mu \mathrm{L}$ of extract, $0.1 \%$ clindamycin, and sterile water into each hole. Incubation for $18 \mathrm{hrs}$ at $37^{\circ} \mathrm{C}$. Diameter of the clear zone was measured using a caliper.

\section{Formulation of gels}

Required quantity of carboxymethyl cellulose was soaked in hot distilled water for 15 minutes (Phase I). The garlic juice was dissolved in the 
propylene glycol, then tartaric acid, benzoate sodium and citrus oleum were added (Phase II). Phases I and II were mixed, and the remaining quantity of distilled water was added to make up the final $100 \mathrm{~g}$ weight. Stir the formulation with a mechanical stirrer to homogenize the formulation (Table 1).

\section{Gel evaluation}

a. Physical evaluation: Physical parameters such as color, appearance, and odor were examined by organoleptic.

b. Determination of $\mathrm{pH}: \mathrm{pH}$ of $1 \%$ aqueous solution of the formulation was measured using a calibrated digital $\mathrm{pH}$ meter at constant temperature [12].

c. Determination of viscosity: Viscosities of the formulated gel were determined using a Brookfield Viscometer. Spindle No. 7 and spindle speed $60 \mathrm{rpm}$ at $25^{\circ} \mathrm{C}$ were used for gels, the corresponding dial reading on the viscometer was noted and multiplied by the factor given in the viscometer catalog.

d. Determination of anti-acne activity: The bacteria suspension $(25 \mu \mathrm{L})$ and $20 \mathrm{~mL}$ of nutrient agar were dispensed into sterile Petri dishes and allowed to solidify $(\mathrm{n}=3)$. The solid agar was riddled with a perforator, then put $50 \mu \mathrm{L}$ of FI, FII, FIII, and sterile water into each hole. Incubation for $18 \mathrm{hrs}$ at $37^{\circ} \mathrm{C}$. Diameter of clear zone was measured using a caliper.

e. Skin irritation test: There were 20 volunteers with various ages. The gel preparation $(0.25 \mathrm{~g})$ on the back of the right hand and the gel base $(0.25 \mathrm{~g})$ on the back of the left hand by the volunteers was applied and left for 60 minutes, then observed changes in skin color. Applied gels were covered with sterile pads for $24 \mathrm{hrs}$, then observed again. Primary irritation was shown by the skin reaction immediately after use, whereas secondary irritation was shown after few hours after usage.

f. Hedonic test: There were 20 volunteers with various ages. The parameters were texture, color, and odor. The assessment criteria were (1) liked extremely, (2) liked slightly, (3) neutral, (4) disliked extremely, and (5) disliked slightly [13].

\section{RESULTS}

The garlic bulbs $(500 \mathrm{~g})$ were produced $73 \mathrm{~g}$ of extract, and the rendement was $14.6 \%$. The phytochemical screening results showed that the garlic juice contains alkaloids, saponins, tannins, monoterpenes, and sesquiterpenes.

The gels were light cream-colored with specific odor, the gel color became more darker during storage (Fig. 1). The optical density of garlic juice and gels was $50 \%$ and $37.56 \pm 1.78 \%$, respectively. The $\mathrm{pH}$ gels were stable for 49 days (Fig. 2), but the viscosity was decreased (Figs. 3 and 4).

\section{DISCUSSION}

Extraction was conducted by extortion without solvent addition to obtain the secondary metabolites optimally and to degradation prevention. The rendement was high (14.6\%). The phytochemical screening results were consistent with literature $[7,14]$. The clear zone showed that the garlic juice has an antimicrobial activity to P. acnes

Table 1: Formulation of gels

\begin{tabular}{llll}
\hline Ingredients (\%) & \multicolumn{2}{l}{ Formula } & \\
\cline { 2 - 4 } & FI & FII & FIII \\
\hline Garlic juice & 7.5 & 7.5 & 7.5 \\
Carboxymethyl cellulose & 2.0 & 2.5 & 3.0 \\
Propilenglicol & 15 & 15 & 15 \\
Benzoic sodium & 0.1 & 0.1 & 0.1 \\
Tartaric acid & 0.035 & 0.035 & 0.035 \\
Citrus oleum & 3 & 3 & 3 \\
Aqua ad & 100 & 100 & 100 \\
\hline
\end{tabular}

compared to clindamycin as standard (Fig. 5). Alkaloids of garlic juice inhibit the bacterial growth or lysis the bacteria cells. Tannins disrupt the bacteria performance of amino acids absorption by the proteolytic inhibition [15].

A single dose for anti-acne is $30 \mathrm{mg}$ of garlic juice empirically, so $100 \mathrm{~g}$ of gel was required $7.5 \%$ of garlic juice. The gels were light cream-colored with specific odor, because of white-yellowish of turbid-garlic juice with strong specific odor. Sodium benzoate as a preservative was used to maintain the stability of secondary

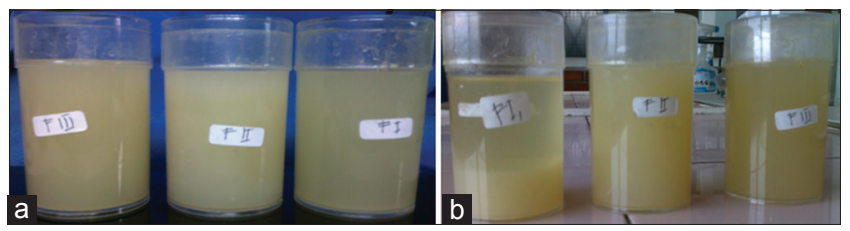

Fig. 1: FI (2\% carboxymethyl cellulose [CMC]), FII (2.5\% CMC), and FIII ( $3 \%$ CMC) of garlic juice at 0 day (a) and 49 days (b) $(n=3)$

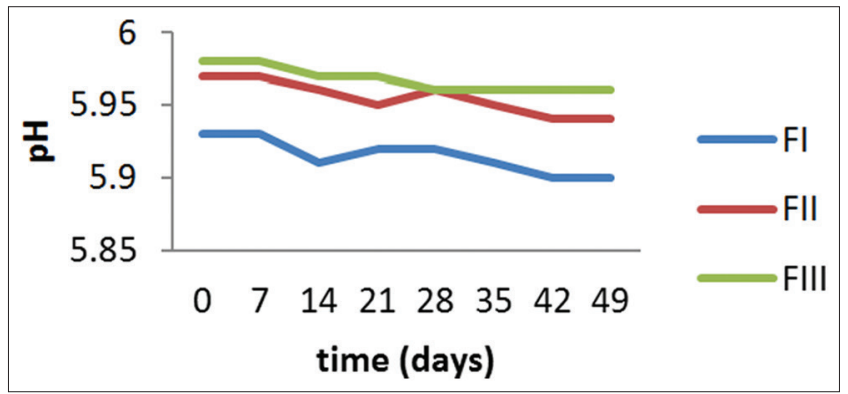

Fig. 2: The gel $\mathrm{pH}$ during 49 days $(\mathrm{n}=3)$

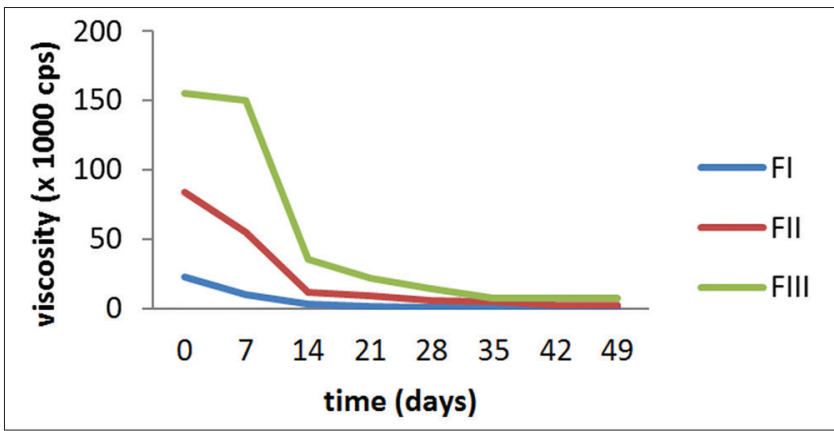

Fig. 3: The gel viscosity for 49 days $(n=3)$

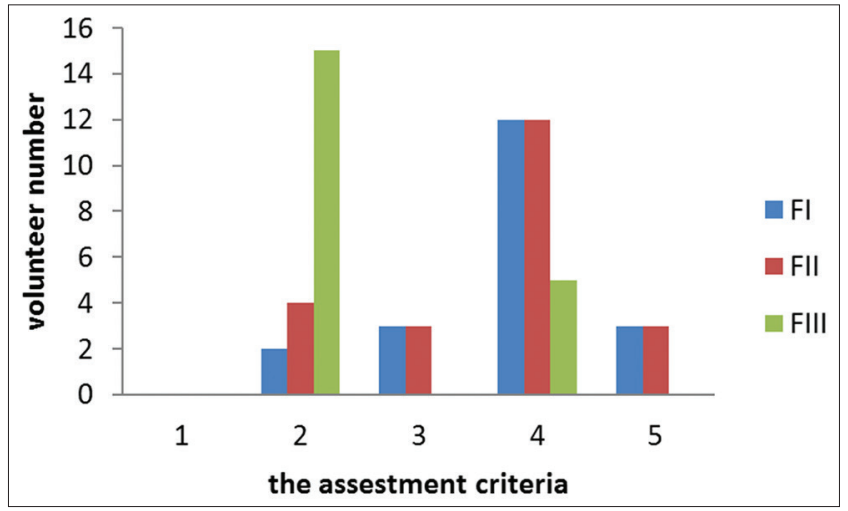

Fig. 4: Hedonic test result: (1) Liked extremely, (2) liked slightly, (3) neutral, (4) disliked extremely, and (5) disliked slightly $(n=20)$ 


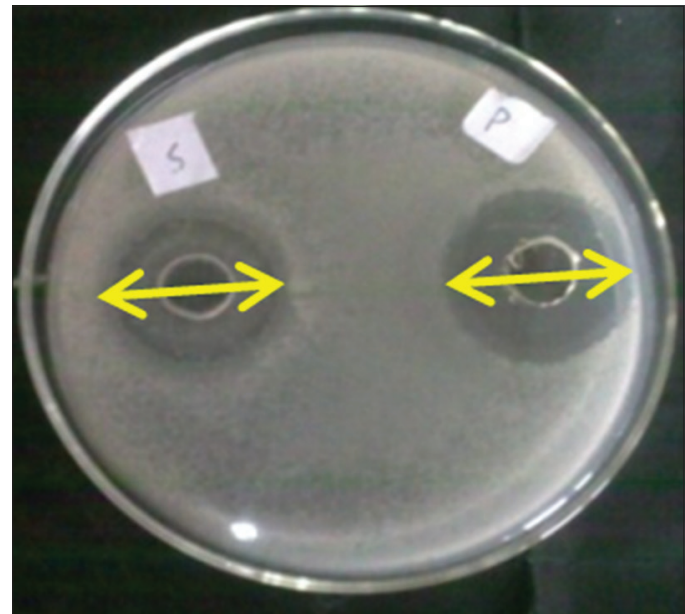

Fig. 5: Antimicrobial activity of garlic juice $(S)$ and clindamycin (P) $(n=3)$

Table 2: Anti-acne activity of gel

\begin{tabular}{lll}
\hline Formula & \multicolumn{2}{l}{ Clear zone $(\mathbf{m m})$} \\
\cline { 2 - 3 } & $\mathbf{0}$ day & 49 days \\
\hline FI & $16.13 \pm 0.013$ & 0 \\
FII & $17.15 \pm 0.009$ & 0 \\
FIII & $17.29 \pm 0.011$ & $15.67 \pm 0.011$ \\
\hline
\end{tabular}

Values are mean $\pm S D(n=3)$

metabolites in the gels by inhibits the oxidation and microbial growth [16]. The gels were stable for 49 days, but the FI showed the syneresis on the $35^{\text {th }}$ day, because of the lowest carboxymethyl cellulose (CMC) concentration $(2.0 \%)$.

The $\mathrm{pH}$ values of gels met the criteria for topical preparation, i.e., 5.0-7.0 [16]. The CMC solutions are non-Newtonian fluids. The viscosity will be increased with increasing concentrations [17]. Higher CMC concentration made more viscous gel, but there is CMC - propylene glycol interaction, so the gel viscosity was decreased (Fig. 3). The results showed that the CMC concentration is not enough to stabilize the gels [18]. The CMC concentration can be increased until $6 \%$ as gel-forming agent [19]. The gels were had anti-acne activity to P. acnes at 0 day. After 49 days, FIII was the only formula which has anti-acne activity (Table 2). It had because of FIII has the highest CMC concentration (3\%), and the gel was the most viscous which can trap the volatile compounds in the garlic juice. The gels does not cause primary and secondary skin irritation $(n=20)$. It is because of all ingredients have the pharmaceutical grade, and the process was hygiene, so there is no microorganism contamination. Most volunteers (75\%) were chosen the FIII as the best formula, because of the most viscous, easy to wash, and comfortable when applied on the skin.

\section{CONCLUSION}

The garlic juice at $7.5 \%$ has anti-acne activity to $P$. acnes, and the gel of $3 \%$ CMC is the most stable and preferable.

\section{ACKNOWLEDGMENTS}

The authors thank to Ardian Baitariza and Riana Widyaningsih for technical assistance.

\section{REFERENCES}

1. Williams HC, Dellavalle RP, Garner S. Acne vulgaris. Lancet 2012;379(9813):361-72.

2. Coenye T, Peeters E, Nelis HJ. Biofilm formation by Propionibacterium acnes is associated with increased resistance to antimicrobial agents and increased production of putative virulence factors. Res Microbiol 2007;158(4):386-92

3. Toyoda M, Morohashi M. Pathogenesis of acne. Med Electron Microsc 2001;34(1):29-40

4. Webster GF. Acne vulgaris. BMJ 2002;325(7362):475-9.

5. Chomnawang MT, Surassmo S, Nukoolkarn VS, Gritsanapan W. Antimicrobial effects of Thai medicinal plants against acne-inducing bacteria. J Ethnopharmacol 2005;101(1-3):330-3.

6. Ministry of Health of Republic Indonesia. Materia Medika Indonesia. Jakarta: Direktorat Jenderal Pengawasan Obat Dan Makanan; 1995.

7. Ross ZM, Maslin DJ, Hill DJ. The effect of steam distilled garlic oil on lactic acid and other enteric bacteria. FEMS Microbiol Rev 2000;12:137-42.

8. Mishra N, Behal KK. Antimicrobial activity of some spices against selected microbes. Int J Pharm Pharm Sci 2010;2(3):187-96.

9. Kodera Y, Ichikawa M, Yoshida J, Kashimoto N, Uda N, Sumioka I, et al. Pharmacokinetic study of allixin, a phytoalexin produced by garlic. Chem Pharm Bull (Tokyo) 2002;50(3):354-63.

10. Farnsworth NR. Biological and phytochemical screening of plants. J Pharm Sci 1966;55(3):225-76.

11. Bauer AW, Kirby WM, Sherris JC, Turck M. Antibiotic susceptibility testing by a standardized single disk method. Am J Clin Pathol 1966;45(4):493-6.

12. Dept Essential Drugs and Medicines Policy. Monograph on Selected Medicinal Plants. Geneva, Switzerland: World Health Organization; 2002.

13. Stone H, Sidel JL. Sensory Evaluation Practices. St. Louis, Missouri, USA: Academic Press; 2004.

14. Sharma A, Patel VK, Rawat S, Ramteke P, Verma R. Identification of the antibacterial component of some indian medicinal plants against Klebsiella pneumoniae. Int J Pharm Pharm Sci 2010;2(3):123-7.

15. Harborne JB. Phytochemical Methods: A Guide to Modern Techniques of Plant Analysis. London: Thompson Science; 1998.

16. Sakurai T. Sodium benzoate. In: Rowe RC, Sheskey PJ, Quinn ME, editors. Handbook of Pharmaceutical Excipients. $6^{\text {th }}$ ed. London, Chicago: Pharmaceutical Press and American Pharmacists Association; 2009. p. 627-9.

17. Lachman L, Lieberman HA, Kanig JL. The Theory and Practice of Industrial Pharmacy. New York: Varghese Publishing House; 1989.

18. Reiger M. Harry's Cosmeticology. Boston: Chemical Publishing Co. Inc.; 2009.

19. Hooton JC. Carboxymethylcellulose. In: Rowe RC, Sheskey PJ, Quinn ME, editors. Handbook of Pharmaceutical Excipients. $6^{\text {th }}$ ed. London, Chicago: Pharmaceutical Press and American Pharmacists Association; 2009. p. 119-21. 